\title{
Effects of Agency Banking on Bank Performance: A Case of Equity Bank Meru Branch, Kenya
}

\author{
Kirima Lucy Karimi \\ School of Business, University of Embu, P.O BOX 158-60401 Chogoria, Kenya
}

Tel: 254-720-627-460Ｅ-mail: mukathakinyua60@gmail.com

Received: August 2, 2018 Accepted: September 12, 2018 Published: November 21, 2018

doi:10.5296/ber.v8i4.13941 URL: https://doi.org/10.5296/ber.v8i4.13941

\begin{abstract}
The purpose of this study was to establish the effects of agency banking on bank performance with a focus of Equity Bank Meru Branch, Kenya. The reason for the selection of Equity Bank was because of its large customer base and because of its growth. The study adopted a descriptive research design and the target population was the eighteen agency bank agents. The study used stratified random sampling to select 11 agents that were used in the study. Both quantitative and qualitative data was collected by use of questionnaires with both open and closed ended questions. Data was analyzed and presented using descriptive statistical tools. The study findings indicated that the general cost such as operations and transactions cost were still high even for agency banking, security measures were in place that is physical security though it needed strengthening, transaction security and customer security were not good and needed improvement and the regulations that were in place for agency banking also needed to be improved. The study made the following recommendations: For agent banking operations to be effective, strong internal control systems should be put in place which should be flexible and be evaluated periodically to increase efficiency and effectiveness; there should also be frequent updates of regulations and policies that guide agency banking and procedures that are used in the banking and agency industry in Kenya. Bankers Association in consultation with the Central Bank of Kenya should carry out frequent audit and research in relationship to agency banking to determine any loopholes and challenges in order to advice the banks accordingly. Also banks should work closely with the agents in order to streamline the systems and processes to help achieve efficiency. The results gathered out of the audit and research will help the banks to keep their agents updated.
\end{abstract}

Keywords: Agency banking, Bank agent, Equity agent, Performance

\section{Introduction}

Banks today have gone through change with introduction of electronic banking with many 
benefits being realized like flexibility in customers' service and low cost of banking. Banks have been able to come up with new banking ways such as ATM and agency banking. An agency bank is a business, company or an organization that acts on behalf of the bank to do. It cannot accept deposits or give loans in its own name; it acts just as an agent for the parent bank. Agency banks can be referred to as retail outlets contracted by financial institutions. Instead of a branch teller, it is the owner of the business or an employee of the business outlet who conducts the transaction and lets clients deposit, withdraw, and transfer funds, pay their bills, inquire about an account balance, or carry out other accepted transactions. Agency banking model requires commercial banks to rely on the already existing institutions or business such as limited liability companies, cooperative societies, parastatals, trusts, partnerships or individuals (CBK, 2014).

\subsection{Equity Bank Agency Banking}

There are several banks in Kenya which have Agency banking such as Diamond Trust Bank (DTB), Equity bank, Family bank, Co-operative bank of Kenya, Chase Bank and Kenya Commercial Bank (Herbling, 2010). Kenya is advancing in terms of technology and therefore is adopting the latest banking technological advancement but also developing new ways of doing business. Agency banking was introduced in Kenya in August 2010 by the central bank of Kenya as a new way of a banking system, from the traditional banking hall system of queuing customers are able to carry out many transactions in an easy and accessible way (Venkata and Mishra, 2013).

Equity bank is growing tremendously as one of the largest banks in East Africa. Though the bank continues to invest in rolling out brick and mortar bank branches many Kenyas still have challenges of accessing formal financial services. In Kenya People live far and wide in the interior rural areas therefore they travel long distance in search for bank services which involves the cost of travel, as well as time spent for travel and waiting in the long queues in the banks. As a result of this, in 2010 Equity bank started its Agency banking business model using mobile phone and point-of-sale (POS) technology. Equity bank refers an "Equity Agent" as a commercial entity that has been contracted by Equity bank offer specific products and services on behalf of the bank at their outlet, and must be duly approved by the Central Bank of Kenya. This entity is then equipped with the skills necessary to provide basic banking services according to standards set by the bank (Venkata \& Mishra, 2013). Equity bank Agencies offers basic services and Equity Bank in future has plans to offer a wide range of products and services to customers without visiting the parent branches. This will enable the customers to access fast, convenient and affordable banking (Venkata \& Mishra, 2013).

Equity banks success strategy on agency business is to rollout and manage Agents through its branches instead of using a third party agent company to do it. An equity parent branch supports the Agent branches with activities and processes such as recruitment, training, branding, marketing, liquidity management, operations support and monitoring. The head office also supports with a centralized contact center. More so, in order to reach people across the country, the bank has an independent Agency banking department which reports directly to Director of Operations. At the Equity Head Office, the Agency banking team is divided 
into six pillar business developments, which include: distribution, operations, training, customer experience and quality assurance (Venkata \& Mishra, 2013). At the branch level, there is a dedicated Agency Supervisor (AS) who is recruited specifically to take care of the Agency business. The AS reports to the Branch Manager and the Agency banking team at head office. The AS is the prime owner of Agents, therefore, works hard to maximize the supervisor-Agents ratio of not more than 1:40 per branch. If there are more than 40 Agents under a branch, the bank recruits additional supervisors to ensure effective working of the Agents (Venkata \& Mishra, 2013).

\subsubsection{Services offered by Agency banking}

Today Agency banking has enabled bank customers to access the basic banking services such as cash deposit, cash withdrawal and checking of bank balance conveniently and within the comfort of their neighbor-hood. The convenience of access to banking services and the extended hours that the agencies work has been the most attractive features to the customer (as most agencies work between $8 \mathrm{am}$ up to 8pm). The people in the rural areas have heartily welcomed this idea because it easens their struggle to access banking services due to the poor road infrastructure, long distances and high costs. In addition, Banks too have benefited a great deal by reducing long ques because the Agency banking offers the same services as a real bank though not all such as withdrawals, getting mini-bank statement, transfer of funds and cach deposits ,new opening account among others and they are also linked to Equity bank's systems electronically, which eliminates the need for the bank to have a branch to do business (Wafula, 2013).The bank also saves on employment, looking for more bank premises and other costs that come with establishing banking systems, processes and services.

\subsubsection{Statement of the Problem}

Central Bank of Kenya (CBK) understands the challenges the Kenyan banking sectors is facing such as the cost of financial services that people go through and that the majority of the customers are in the rural areas. To address these challenges is to promote innovation and to address the delivery channel costs through increased use of Agent banking (Central Bank of Kenya, 2010). In order to speed up the development of the Agent banking in Kenya, the CBK made use of a knowledge exchange Programme supported by the Alliance for Financial Inclusion (AFI). From the M-PESA mobile phone-based payment service experience, the 2010 Agent banking guidelines allowed banks to start working in partnership with non-bank based models. Therefore, this study sought to establish the effects of Agency banking on bank performance with a focus of Equity bank Meru Branch,Kenya.

\section{Theoretical Literature Review}

\subsection{Effects of Agency Costs on the Performance of Bank}

When financial banks do not have branches that are close to the customer, the customer goes to transact with other services providers that are close to them (Kitaka, 2009). However, the innovation of new delivery models as a way of banking has helped the banks to be able to reach customers wherever they are in the world today. Through Agency banking, banks are 
able to provide banking services in an easy viable way to the customers because it provides convenience and reduces the cost. According to Podpiera (2008), the new model of Agency banking improves the economic status of the Agents because customers find it convenient to carry out transactions with the Agency than going to the bank. Kithaka (2009) indicates that the transactions carried out by the Agency gives the cost and revenue estimation. These include the number of deposits, savings accounts transactions and reverse commitment accounts. The assumptions of revenue are made on the basis of charges for withdrawals and transfers through Agent channels. Gardner (2010) says that Agent banking systems are three times cheaper to operate than branches because Agent banking minimizes fixed costs by leveraging existing retail outlets and reducing the need for banks to invest in their own infrastructure. Although

This argument is further supported by Kitaka (2009) who argues that setting up an Agent is cheaper than the cost of employing ( costs 2 to 4 percent) a branch cashier. So even when operating at maximum capacity, a branch cashier incurs higher costs per transaction per transaction (78 cents in fixed costs per transaction) compared to Agents .Using banking Agents banks are able to acquire entrepreneurs at less cost of a branch or POS-enabled Agent. Kitaka (2009) noted that, in many developing countries, banks have expanded their network through trusted local "Agents" or "correspondents" to offer their services. The sector has witnessed a rapid growth in the last ten years. For instance, whereas previously many banks focused on traditional banking, Agents in a number of countries are now authorized to offer many of the traditional products offered by banks. Banks have, therefore, moved up the ladder of product range to offer more sophisticated banking products such as bank supported insurance and asset financing products

\subsubsection{Effects of Agency Security on the Performance of Banks}

Lyman and Stschem (2006) says that funds of clients should be protected and this should be a priority by the financial regulators because loss of funds impacts on customers badly thus making them loss confidence with the financial systems. Banks are expected to comply with the given rules to ensure safe systematic and depositor protection. Bank also has insurances that cover deposits done by customers. However, in emerging branchless banking models, nonbanks are allowed to collect funds, without full range of prudential rules imposed on banks. Also, there may be models client funds can be in a bank account and this enables them to receive special regulatory treatment than those applicable to bank deposits.

Countries which have branchless banking models have different ways of handling and protecting client's funds. For example, in Philippines, there are accounts referred to as smart money accounts balances which are deposited in the clients name in a commercial bank but they are considered as accounts payable on the bank's books rather than deposits. So even although it is a bank based model, its regulatory treatment is different from that of bank deposits. Another case is that of Russia, the web based stored value services does not follow any regulatory standard for safeguarding client funds. More so, the M-pesa funds that customers use is on short-term savings mechanism(Collins 2010). This fund is deposited in pooled trust accounts in different commercial banks but there is no system is in place for 
customers to claim trust assets. In 2006, the CBK and CCK and the Ministry of Finance supported the rollout of safaricom 's mobile phone base money transfer product M-pesa, through Safaricom as the implementing agency and not a commercial bank. In 2009 the finance Act was amended to facilitate use of third parties by banks to provide banking services. Central banks Agent banking guidelines (CBKK/PG/15) issued in 2010(central bank website) to regulate agency banking.

In today's branchless banking system the challenge is providing security at the network layer without implementing any application -layer cryptography. For example, M-pesa which is widely used in Kenya it serves over $50 \%$ of Kenyas population, uses a custom-made SIM Tool Kit (STK) program to protect transaction messages exchanged between client phones and the server.Many do not know how the system works although recently it has experienced attacks. Other key players like G-cash in the Philippines rely directly on GSM"es default security services to protect client information but these services are known to offer very weak security guarantees; in, it is argued that vulnerabilities in $\mathrm{GSM}^{\mathrm{ee}}$ s security suite could be used to deliver subvert G-cash transactions. Indeed, the question of what application-level security means in the context of branchless banking does not seem to be well-understood yet, neither in the academic literature nor in practice (Collins2010).

Challenges found in informal financial services are lack of reliability and continuity. Formal providers have ways that help them to offer more reliable and safer services. This can be facilitated by technology-enabled mechanisms. Some studies suggest problems like equipment malfunctioning and other errors occur during transactions. A study by Collins (2010 on consumer experience in Brazil shows that less than 5 percent of users make mistake and paid the wrong bill at an agent, sent money to the wrong account, or noticed that a payment or a deposit was never processed or received.

\subsubsection{Effects of Agency Regulation on the Performance of Banks}

Collins (2009) explains the struggles that the poor people face to manage their little finances in terms of saving and deposits. For example, M-pesa in Kenya is a case of innovative business model that helps the low earning people to be able to carry out deposits and other transactions with reduced risks and protection. M-pesa is examples that other providers can offer such services with transparency and adopt measures that will safeguards and protect consumers. Since protecting clients funds is the first priority of any financial provider, Lyman and Stschem (2006) indicate that banks are usually required to comply with the policies, rules and regulations and prudential rules provided to ensure safe systematic and depositor protection. An agency regulation helps the agents to be able to carry out their transactions effectively and efficiently and to safeguard the customer's funds. It also helps them to know how to link and work with the banks.

\section{Research Methodology}

\subsection{Research Design}

The study used descriptive research design. A descriptive study is used to describe problems, people or events through collection of data and tabulation of the frequencies on research 
variables or their interaction (Cooper, 2003). Descriptive research design was chosen because it enabled the study to generalize the findings to a large population. The descriptive research approach was appropriate due to the fact that it allowed analysis and relation of variables of the study due to similarities of Agency banking in different parts of the country.

\subsubsection{Population of the Study and Sampling Design}

The target population for this study was Equity bank Meru Branch. The study targeted Equity Bank Meru Branch and the eighteen Equity bank Agents offering the service. The study used stratified random sampling to select the sample size. According to Collis and Hussey (2003), $60 \%$ of a given sample size in a population is able to give reliable representation of the required response. Therefore 11 agents were studied.

\subsubsection{Data Collection Method}

The study collected data using a questionnaire with both open and closed ended questions. The questionnaire was chosen as an instrument for the study because it was appropriate to the research problem and the size of the population.

\subsubsection{Data Analysis}

Data was analyzed using descriptive statistics such as frequencies and percentages. In addition, inferential statistics were also used in the data analysis. Data was analyzed according to the objectives of the study.

\section{Results and Discussion}

\subsection{Agency Cost on Performance of a Bank}

On the Agency cost on performance of a bank, it was found out that $61.2 \%$ felt that transaction cost had a major influence on performance of the Agency, $30.6 \%$ said infrastructure cost had an effect on the performance of the Agency and 8.2\% had no effect at all. This confirms the study by Wangari (2012) on the role of Agency banking on the performance of commercial banks in Kenya, which concluded that infrastructure cost and security influence the performance of commercial attributable to Agency banking to a great extent.

Table1. Areas of cost influence on performance of Agent bank

\begin{tabular}{|l|l|l|}
\hline Agents performance & Frequency & Performance \\
\hline Transaction cost & 6 & $61.2 \%$ \\
\hline No extent & 1 & $8.2 \%$ \\
\hline Infrastructure cost & 3 & $30.6 \%$ \\
\hline Total & 10 & $100 \%$ \\
\hline
\end{tabular}

\subsubsection{Agency Security on Bank Performance}

On agency security, $13 \%$ of the respondents indicated their security was very strong, $27 \%$ responded it as strong, $40 \%$ was moderate while $20 \%$ response was that the security was weak. This indicated that the security system in place both physical and technological was 
not a major concern to the Agents. This disagrees with a study by Wangari (2012), which found that security systems by Agent banks was not the required standards and therefore recommended that Agency banking should be given more attention on security measures including risk-based approach and that the banks should find better ways of screening their Agents to ensure that large cash transactions handling is effectively carried out on their behalf. In addition, on security implementation expense $80 \%$ of the respondents felt that installing high security equipment like the CCTV cameras was expensive while $20 \%$ were comfortable and ready to incur such cost. The results indicate majority of Agents do not have financial capability for such an expensive venture because majority of agencies around the country are owned by middle class businesses and type of businesses that do not yield high profits.

Table 2.

\begin{tabular}{|l|l|l|}
\hline Level of security & Frequency & Percentage \\
\hline Very strong & 10 & $12.50 \%$ \\
\hline Strong & 22 & $27.50 \%$ \\
\hline Moderate & 32 & $40 \%$ \\
\hline Very low & 16 & $20 \%$ \\
\hline Very weak & 0 & $0 \%$ \\
\hline Total & 80 & $100 \%$ \\
\hline
\end{tabular}

\subsubsection{Agency Regulation on Bank Performance}

On agency regulation, $60 \%$ said banking operations resulted in operational risk; $30 \%$ felt that there was a mild increase in liquidity risk; $10 \%$ felt there was the credit risk. The reason for having high operational risk is due to agency banking being a new model of banking, is prone to human error that can lead to Agency at different times failing to operate consistently, liquidity risk was a result of lack of Agents having low float to operate with and credit risk because the lowest majority customers preferred to deal with the bank branch directly on matters to do with the repayment of credit advanced to them. Wangari (2012) the role of Agency banking in the performance of commercial banks, indicated that operational risk and liquidity risk were the major risk faced by agents. More so, on agency regulation $72.5 \%$ responded that they have had issues with the Agent, while 27.5\% said that they did not have issues. Issues brought out as main reasons were systems delay, at times there was delay before the transaction for example of withdrawal is executed. Other issues had to do with the Agent not having available funds in the case of large amount.

Table 3. Challenges faced by Agents

\begin{tabular}{|l|l|l|}
\hline Challenges faced by Agents & Frequency & Percentage \\
\hline Operational risk & 6 & $60 \%$ \\
\hline Liquidity risk & 3 & $30 \%$ \\
\hline Credit risk & 1 & $10 \%$ \\
\hline Total & 10 & $100 \%$ \\
\hline
\end{tabular}




\section{Conclusion}

On the cost, the study concluded that general cost such as operation and transaction cost were still high, as those at the bank thus creating the perception to the customers that there was no need of seeking Agency services. This gives the view that Agency banking may in the long run fail to decongest banking institutions. Agents also felt that the costs did not enable them to earn enough profits as they would have anticipated. In addition, It was also concluded that security measures in place that is physical security, transaction security and customer security was not to the standard of an institution running financial transactions. More so, it was noted that the regulations were able to stream line Agency banking operations because there were low cases reported in relation to Agents, which helped to boost confidence of the customers on Agency banking.

\section{Acknowledgement}

I thank Joshua Kimani Muturi for his invaluable contributions towards this work.

\section{Reference}

African Alliance, (2009). Kenya Banking Review: Sector Report

Arora, S., \& Ferrand, D. (2007). Meeting the Challenge of Creating an Inclusive Financial Sector. Paper Presented During DFID And HM Treasury Financial Inclusion Conference, London.

Atandi, G. (2013). Challenges of Agent banking experiences in Kenya: Survey. https://doi.org/10.6007/IJARBSS/v3-i8/161

Berger, A. N. (2003). The Economic Effects of Technological Progress: Evidence from the Banking Industry. Journal of Money, Credit, and Banking, 35(2), 141-176.

https://doi.org/10.1353/mcb.2003.0009

Bold, C. (2011). Branchless Banking in South Africa. Consultative Group to Assist the Poor $(C G A P)$.

Central Bank of Kenya. (2011). Annual report. Retrieved on 5th March, 2014 from

Collins, D. (2010). Consumer Experience in Agency Banking. Presentation at the III Windsor Global Leadership Seminar in Regulating Transformational

Collis, J., \& Hussey, R. (2003). Business Research: a practical guide for undergraduate and postgraduate students, second edition. Basingstoke: Palgrave Macmillan.

Equity Bank. (2013). Registered Equity bank Agents. [Online] Available: www.equity.co.ke/index.phplbranches/view/meru

Gakure, R., \& Ngumi, P. (2013). Do Bank Innovations Influence Profitability of Commercial Banks in Kenya. Prime Journal of Social Science, 2(3), 237-248.

Gardner, M. J., \& Cooperman, E. S. (2010). Managing Financial Institutions an Assets Liability Approach, (4th ed.) Malaysia, Asia. John Wiley \& Sons. 
Irechukwu, G. (2000). Enhancing the Performance of Banking Operations Through Appropriate Information Technology, In: Information Technology in Nigerian Banking Industry. Spectrum Books. Ibadan. 63-78.

Lauer, K., Dias, D., \& Tarazi, M. (2011). Bank Agents: Risk Management, Mitigation, and Supervision. Focus Note 75. Washington, D.C.: CGAP Publication

Kasekende, A. L. (2008). Africa Continues Steady Growth. Presentation Paper at the Africa Forum. Unpublished Paper, University of Johannesburg.

Khera, S. (2009). Agency Banking Outlook in Africa. Mumbai India: Agile Financial

Kitaka P. (2009). A Survey of the use of Financial Performance Indicators by Micro FinanceInstitutions in Kenya. Unp blished MBA Research Project, University of Nairobi.

Mas, I. (2008). Realizing the Potential of Agency Banking: Challenges Ahead.

Venkata, N. A., \& Mishra, P. (2013, April). Success Factors of Equity Bank's Agency Banking. [Online] Available: www.microfmancegateway.org.

Wafula, P. (2013, September 23). Agency Banking. The Business Daily, pp. A12.

Wangari, R. M. (2012). An evaluation of the role of agency banking in the performance of commercial banks in Kenya. Kenyatta University: Unpublished Study Report.

Wawira, N. J. (2013). Contributions of agency banking on financial performance of commercial banks in Kenya. Kenyatta University: Unpublished Manuscript.

\section{Copyright Disclaimer}

Copyright for this article is retained by the author(s), with first publication rights granted to the journal.

This is an open-access article distributed under the terms and conditions of the Creative Commons Attribution license (http://creativecommons.org/licenses/by/3.0/). 